\title{
Evolution of the Neuron-Specific Alternative Splicing Product of the c-src Proto-Oncogene
}

\author{
F. Raulf, S.M. Robertson, and M. Schartl \\ Genecenter, Max-Planck-Institute for Biochemistry, Munich-Martinsried, Federal Republic of Germany
}

The observation of a slower migrating form of pp60 $60^{c-s r c}$ in neural tissue of chicken and mouse has recently been shown to be due to an alternative transcript form of the c-src gene (Martinez et al.: Science 237:411-415, 1987; Levy et al.: Mol Cell Biol 7:4142 4145,1987 ). An insertion of 18 basepairs between exons 3 and 4 , presumed to be due to alternative splicing of a mini-exon, gives rise to six amino acid residues not found in the non-neuronal (termed fibroblastic) form of $p p 60^{c-s r c}$.

We have addressed the question of the evolutionary origin of the c-src neuronal insert and its functional significance regarding neural-specific expression of the c-src gene. To this end we have investigated whether the c-src gene of a lower vertebrate (the teleost fish Xiphophorus) gives rise to a neural-specific transcript in an analogous manner. We could show that the fish c-src gene does encode for a "fibroblastic" and a "neuronal" form of transcript and that the neuronal transcript does indeed arise by way of alternative splicing of a mini-exon. The miniexon is also 18 basepairs long and we could demonstrate directly that this exon lies within the intron separating exons 3 and 4.

For comparative purposes we have examined whether the fish c-yes gene, the member of the src gene family most closely related to c-src, also encodes a neural tissue-specific transcript. No evidence for a second transcript form in brain was obtained. This result suggests that the mini-exon arose within the c-src gene lineage sometime between the $s r c / y e s$ gene duplication event and the divergence of the evolutionary lineage giving rise to the teleost fish. Published genomic sequence of src-related genes in Drosophila and our own results with Hydra demonstrate no intron in these species at the analogous location, consistent with first appearance of this mini-exon sometime between 550 and $\mathbf{4 0 0}$ million years ago.

Key words: Xiphophorus, teleost fish, polymerase chain reaction, $\mathbf{R T}-\mathrm{PCR}$, mini-exon, $\mathrm{pp} 60^{\mathrm{c}-s r c}$

\section{INTRODUCTION}

Proto-oncogenes, the cellular homologs of retroviral transforming genes, have been implicated in the regulation of normal cellular processes such as proliferation and differentiation. The c-src gene was the first cellular proto-oncogene detected (Stehelin et al., 1976). It encodes a phosphoprotein of 60,000 daltons (pp60 6 -src) and possesses, like its viral counterpart, a tyrosine-specific kinase activity (for review see Hunter and Cooper, 1985). Expression studies on the $\mathrm{pp} 60^{\mathrm{c}-s r c}$ protein and c-src mRNA have revealed that cells of the neural cell lineage preferentially express the c-src gene although it has also been found that differentiating monomyelocytic cells in vitro (Barnekow and Gessler, 1986; Gee et al., 1986) and blood platelets (Golden et al., 1986) express the gene at elevated levels. Neural tissues contain high amounts of $\mathrm{pp} 60^{\mathrm{c}-s r}$, of its kinase activity (Cotton and Brugge, 1983; Schartl and Barnekow, 1984; Levy et al., 1984; Fults et al., 1985; Maness, 1986), and of c-src mRNA (Gessler and Barnekow, 1984; Simon et al., 1985; Vardimon et al., 1986; Mäueler et al., 1988a). Low levels of c-src mRNA have been detected in several other tissues, including heart, muscle, and liver (Gessler and Barnekow, 1984; Mäueler et al., 1988a).

Investigations on the phylogenetic distribution of the c-src gene and its evolutionary precedents, respectively, have indicated that this gene, appearing first during phylogenesis in the most primitive multicellular animals, the sponges (Barnekow and Schartl, 1984), might therefore be as old as 1.5 billion years. The sequence of the c-src gene has been found to be highly conserved in human (Anderson et al., 1985), mouse (Martinez et al., 1987), chicken (Takeya and Hanafusa, 1983), fish (Rob-

Received March 28, 1989; revised May 17, 1989; accepted May 19, 1989.

Address reprint requests to Friedrich Raulf, Max-Planck-Institut für Biochemie, Genzentrum, Am Klopferspitz 18a, D-8033 Martinsried, West Germany. 
ertson et al., submitted), fruit fly (Hoffmann et al., 1983; Simon et al., 1985), and sponge (Ottilie and Schartl, unpublished). In addition, the enzymatic properties of pp60 c-src have been shown to be comparable in all metazoans tested so far and the preferential expression in neural tissues was also found to be conserved during evolution (Schartl and Barnekow, 1982; Barnekow and Schartl, 1987). This evolutionary conservation already points to a crucial function for this gene in multicellular animals. During ontogenesis it has been demonstrated in various species that pp60-src kinase activity is found preferentially in post-mitotic neurons. In the chicken during embryonal development $p p 60^{c-s r c}$ is detected in the cerebellum and the developing neural retina during terminal differentiation of neurons (Maness, 1986). In the adult chicken brain highest levels of c-src gene expression are found associated with membranes in the molecular layer of the cerebellum and to a lesser extent in the granular layer (Sudol et al., 1988). In the central nervous system of the rat all regions were shown to contain detectable levels of $\mathrm{pp} 60^{\mathrm{c}-\mathrm{src}}$, with areas characterized by a high content of grey matter and an elevated density of synaptosomes displaying the highest amounts of the kinase (Walaas et al., 1988). Localization of c-src mRNA by in situ histochemistry (Raulf et al., 1989) compared with the distribution of $\mathrm{pp60} 0^{\mathrm{c}-s r c}$ (Maness et al., 1988; Sorge et al., 1984) indicated translocation of the c-src-encoded protein product to the processes of nerve cells.

Based on these studies it was deduced that the c-src gene product primarily plays a role in differentiation or maintenance of the neuronal cell phenotype. Recently, a slower-migrating form of $\mathrm{pp} 60^{\mathrm{c}-s r c}$ (termed $\mathrm{pp} 60^{\mathrm{c}-s \mathrm{rc}+}$ ) has been found primarily in the central nervous system of higher vertebrates (Brugge et al., 1985, 1987; Lynch et al., 1986; LeBeau et al., 1987). pp60 $0^{\text {c-src }}{ }^{+}$is encoded by a unique mRNA that contains in contrast to the previously identified protein from non-neuronal cells a six amino acid insertion (Martinez et al., 1987; Levy et al., 1987). pp60 $60^{c-s r c+}$ is preferentially detected in membranes of neuronal growth cones and nerve processes, leading to the suggestion of its possible role in growth cone-mediated neurite extension (Maness et al., 1988).

We have addressed the question of the evolutionary origin of the c-src neuronal insert. For this purpose we have investigated whether this insert can be detected in lower vertebrates, e.g., fish. We also looked for a comparable "neuronal" form of the c-yes gene in these animals. The c-yes gene has arisen due to a gene duplication event involving c-src prior to evolution of modernday teleost fish (Robertson et al., submitted). Although this gene shows a high degree of structural similarity and a comparable preferential expression in neural tissues of chicken (Sudol et al., 1988), it is not known if a specific neuronal form exists. In addition, we examined whether Hydra, the first organism with a defined nervous system and also demonstrating a neural-specific src expression (Schartl et al., submitted), could generate a neuron-specific form of pp60-src in an analogous manner. To elucidate the mechanism by which such altered transcripts arise, two possibilities were investigated; firstly, that the neuronal insert is contained as a "mini-exon" in the intron between exons 3 and 4 and is inserted by an alternative splicing event, as has been suggested (Martinez et al., 1987; Levy et al., 1987); or secondly, that a neuron-specific genomic rearrangement of the c-src locus occurs.

\section{MATERIALS AND METHODS \\ Experimental Animals}

The fish used in this study were bred under standard conditions (see Kallman, 1975) in the aquarium of the Genecenter. The following species were included in our analyses: Xiphophorus helleri (stock "Rio Lancetilla"), and X.maculatus (stock "Rio Usumacinta"), $X$. xiphidium (stock "Rio Purification"), and $X$. helleri backcross hybrids bearing the $T u$-Sd oncogene locus from $X$. maculatus (stock "Rio Jamapa") responsible for the spontaneous development of melanomas (see Schartl et al., 1989a).

The Hydra used in this study (Hydra viridissima) were maintained under standard conditions and obtained from T. Holstein (Zoology Institute, Ludwig-Maximilians-University, Munich, F.R.G.).

\section{Cell Lines}

Cell lines derived either from spontaneous hereditary melanoma of Xiphophorus hybrids, PSM cells (Wakamatsu et al., 1984), or from non-tumorous embryos of wildtype $X$. xiphidium, A2 cells (Kuhn et al., 1979). Cells were cultured in F12 medium (Biochrom, Berlin, F.R.G.) containing $10 \%$ fetal calf serum and $1.25 \mathrm{~g} \mathrm{NaHCO}_{3} / \mathrm{L}$ at $28^{\circ} \mathrm{C}$ under $5 \% \mathrm{CO}_{2}$.

\section{Isolation of Genomic DNA}

Preparation of high molecular weight genomic DNA was according to Blin and Stafford (1976). Prior to PCR the genomic DNAs were treated with RNase A (100 $\mu \mathrm{g} / \mathrm{ml}$ ) at $37^{\circ} \mathrm{C}$ for $1 \mathrm{hr}$.

Restriction enzyme digestions (enzymes from Boehringer Mannheim, Mannheim, F.R.G.) and standard molecular biology techniques were carried out essentially as described (Maniatis, 1982).

\section{Isolation of RNA and Reverse Transcription}

Total cellular RNAs from cell cultures were isolated as described previously (Mäueler et al., 1988a). 
For RNA preparation from fish organs a microscale GuaSCN/CsCl procedure (Chirgwin et al., 1979) was used; e.g., 1-3 freshly dissected fish brains (approx. $15-30 \mathrm{mg}$ ) were homogenized for $1 \mathrm{~min}$ at 25,000 rpm with an Ultra-turrax T5 (Janke \& Kunkel, Staufen, F.R.G.) in $600 \mu \mathrm{l}$ GuaSCN solution (6 M guanidine thiocyanate, $10 \mathrm{mM}$ EDTA, 4\% N-laurylsarcosine, $1 \%$ 2-mercaptoethanol, $200 \mu \mathrm{g} / \mathrm{ml} E$. coli $\mathrm{RNA}$ ). RNA was purified by centrifugation through $5.7 \mathrm{M} \mathrm{CsCl}, 100 \mathrm{mM}$ EDTA pH 8.0 for $2 \mathrm{hr}$ at $18^{\circ} \mathrm{C}$ at $80,000 \mathrm{rpm}$ (TLA 100.2 rotor, TL-100 ultracentrifuge, Beckman, Palo Alto, CA), solubilized in $300 \mu \mathrm{l} 4 \mathrm{M} \mathrm{NH}_{4} \mathrm{Ac}$, and precipitated with ethanol.

For reverse transcription oligo(dT) 15 primer (Boehringer Mannheim, Mannheim, F.R.G.) was annealed to $1-4 \mu \mathrm{g}$ total cellular RNA and incubated with $50 \mathrm{U}$ AMV reverse transcriptase (Life Sciences, St. Petersburg, FL) according to the supplier's recommendations for $1 \mathrm{hr}$ at $42^{\circ} \mathrm{C}$.

\section{Polymerase Chain Reaction}

For RT-PCR 0.1 volume of the first-strand cDNA synthesis was directly introduced into the polymerase chain reaction. Conventional PCR (Saiki et al., 1988) was performed by using about $1 \mathrm{ng}$ genomic DNA. The reaction mix contained further two primers ( $1 \mu \mathrm{M}$ each), all four dNTPs (200 $\mu \mathrm{M}$ each), $50 \mathrm{mM} \mathrm{KCl}, 10 \mathrm{mM}$ Tris- $\mathrm{Cl} \mathrm{pH} 8.3$ (at room temperature), $1.5 \mathrm{mM} \mathrm{MgCl}$, $0.01 \%(w / v)$ gelatin, and 2.5 U Taq DNA polymerase (Perkin Elmer Cetus, Norwalk, CT) in a volume of $50 \mu$ l overlaid with mineral oil. A self-made computer-controlled PCR-machine using a Peltier element as thermoelectric heat pump (Wittbrodt and Erhardt, 1989) was used for 45 cycles of $1 \mathrm{~min}$ at $92^{\circ} \mathrm{C}, 1.5 \mathrm{~min}$ at $60^{\circ} \mathrm{C}$, and $2 \mathrm{~min}$ at $72^{\circ} \mathrm{C}$. Following termination of the reaction the samples were kept at $4^{\circ} \mathrm{C} ; 20 \%$ aliquots of each reaction were analyzed by agarose gel electrophoresis, and the remaining volume was subjected to direct sequencing of the PCR product.

\section{Oligonucleotides}

Oligonucleotides were synthesized on a $380 \mathrm{~A}$ DNA Synthesizer from Applied Biosystems (Foster City, CA).

\#S95 5'AAG AGA CTA AAT CTC CAG GGT
CTT GGC CAT 3'(30mer),
\#S777R 5'GGC GTG CTT GCC GTA TGA TTG
CAC GAG CTG 3'(30mer),
\#S372 5'TAC GAC TAC GAG TCT CGA A
3'(19mer),
\#S515R 5'CCA CAT AAT TGC TGG GGA T
3'(19mer),

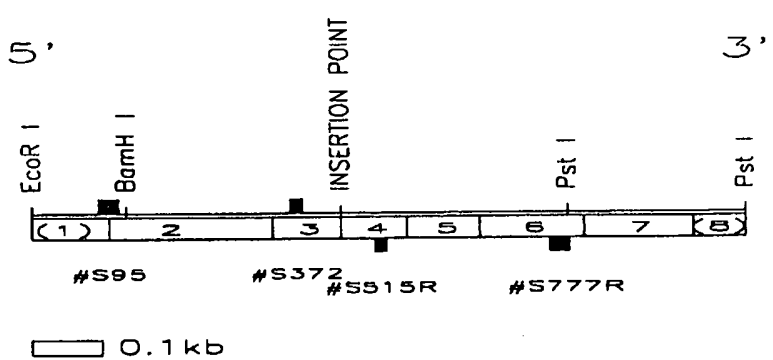

Fig. 1. Partial map of Xiphophorus c-src cDNA from A2 cells (fibroblast form, 1,029bp EcoR I/Pst I-fragment comprising exons 2-7) with the positions marked (filled-in rectangles) of the $s r c$-specific oligonucleotides used in this study in comparison to the exon arrangement. Those oligonucleotides above the bar are in sense orientation, whereas those below the bar are anti-sense. The start of translation is in exon 2 at position 122.

\section{\#SNR 5'CCC TGC AGT TTA TCT TCC TC $3^{\prime}$ (20mer),}

\section{Direct Sequencing of PCR Products}

A 0.1 volume of $2 \mathrm{M} \mathrm{NaOH}, 2 \mathrm{mM}$ EDTA was added to the PCR mix and incubated for $10 \mathrm{~min}$ at room temperature. After addition of 0.1 volume $3 \mathrm{M} \mathrm{NaAc} \mathrm{pH}$ 5.2 an ethanol precipitation was performed. The salt-free washed and dried DNA pellet was subjected to DNA sequencing by using a ${ }^{32} \mathrm{P}$-endlabeled oligonucleotide as primer and the T7 DNA polymerase kit according to the suppliers recommendations (Pharmacia,Freiburg, F.R.G.).

\section{Isotachophoresis}

Cut out DNA fragments were recoverd from agarose gels by isotachophoresis essentially as described (Öfverstedt et al., 1984).

\section{Sequence Analysis}

Sequence comparisons were carried out by using the sequence analysis software package (GCG) of the University of Wisconsin Genetics Computer Group (Devereux et al., 1984).

\section{RESULTS}

\section{Xiphophorus Brain Contains Two Forms of src mRNA}

To investigate if a neuronal insert of the c-src proto-oncogene is already present in lower vertebrates, we used the polymerase chain reaction (PCR) to look for a neuronal c-src form in the teleost fish Xiphophorus. For this purpose oligonucleotide primers were designed based upon a previously cloned and sequenced Xipho- 


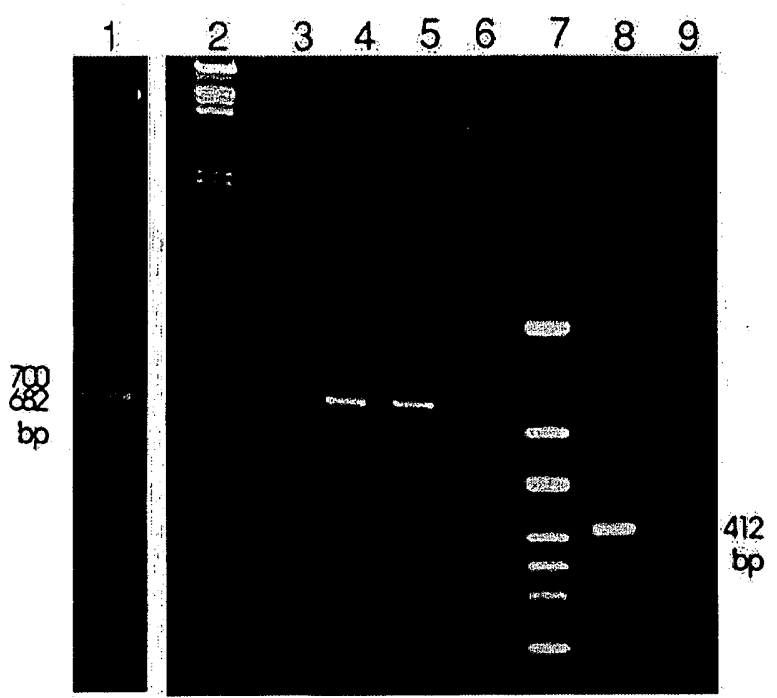

Fig. 2. RT-PCR of total RNA from Xiphophorus tissues and cell lines. Lanes 1,3-6: Polymerase chain reaction with c-src primers \#S95 and \#S777R. (1) X. xiphidium brain, (3) X. helleri brain, (4) A2 cells, (5) PSM cells, (6) a control experiment with water instead of template. Lanes 8 and 9: Polymerase chain reaction with c-yes primers (see text). (8) $X$. helleri brain, (9) $X$. helleri liver. Size of PCR products as marked (in basepairs). Lane 2: Molecular weight marker $\lambda$ / EcoR I + Hind III. Lane 7: Molecular weight marker pBR322/EcoR I + Hinf I.

phorus c-src cDNA (Raulf, unpublished). This cDNA clone was derived from an embryonal cell line (A2) and represents the fibroblast form of c-src (Fig. 1). To analyze the c-src mRNA the primer set \#S95 and \#S777R were designed as 30 mers spanning $682 \mathrm{bp}$ between exon 2 and exon 5 including the expected (i.e., by analogy to the mouse and chicken) insertion point at the border of exons 3 and 4.

PCR after first-strand reverse transcription (RTPCR) revealed two distinct fragments from total brain RNA preparations of $X$. xiphidium and $X$. helleri (Fig. 2, lanes 1 and 3). To test the fidelity of the reaction total RNA from A2 cells was used in parallel. This reaction yielded only the $680 \mathrm{bp}$ fragment, representing the fibroblast form as expected from the cDNA data (Fig. 2, lane 4). The faster-migrating fragment of the brain PCR product comigrates with the A2 PCR product and therefore is regarded to represent the amplification product of the fibroblast form. The additional, about $20 \mathrm{bp}$ longer, PCR product was presumed to represent the neuronal form of fish c-src. Both bands hybridized in Southern blot analysis to the ${ }^{32} \mathrm{P}$-labeled exon 3 -specific oligonucleotide \#S372 which was designed 73bp upstream from the expected insertion (data not shown). This result confirmed that both amplification products derived from the Xiphophorus c-src locus.

To address the question of whether c-src in other cells of the neural cell lineage can also give rise to a transcript with a neuronal insert, RNA from a Xiphophorus melanoma cell line (PSM) was analyzed. This cell line, composed of transformed melanocytes, has been shown to contain high levels of c-src mRNA and pp60 ${ }^{c-s r c}$ kinase activity (Mäueler et al., 1988b). The resulting single PCR band had the size of the fibroblast form (Fig. 2, lane 5).

\section{Length and Location of the Neuronal Insert Are Conserved in Fish}

For sequence analysis both RT-PCR bands from brain were separated by gel electrophoresis on a $1.8 \%$ agarose gel. The bands were cut out, purified by isotachophoresis, and sequenced by using ${ }^{32} \mathrm{P}$-labeled oligonucleotide \#S372. In parallel, unpurified PCR product from A2 cells and PSM cells were subjected to sequence analysis. In addition, the higher molecular weight band from brain was subcloned and sequenced by standard plasmid ${ }^{35} \mathrm{~S}$ sequencing. These sequence analyses revealed that the higher molecular weight band from brain contained, in comparison to the A2 and PSM bands and the lower molecular weight band from brain, an $18 \mathrm{bp}$ insertion exactly at the exon $3 / 4$ border (Fig. 3), completely analogous to the situation in mouse (Martinez et al., 1987) and chicken (Levy et al., 1987). The neuronal insert sequence itself when compared to the corresponding mouse sequence is less conserved $(61 \%$ on nucleic acid, $50 \%$ on amino acid level) in contrast to the situation found for exons $3(78.4 \% \mathrm{NA}, 90.6 \% \mathrm{AA})$ and exons $4(85.9 \% \mathrm{NA}, 87.9 \% \mathrm{AA})$. The most striking difference is the exchange of valine for cysteine in the fifth amino acid position of the neuronal insert (Fig. 3). This results in a new Pst I site, which was used as a diagnostic marker site for the neuronal fish c-src form. Comparison of the neuronal insert sequence from fish and chicken gives the same values as the fish-mouse comparison above.

\section{The Neuronal Insert Is a Mini-Exon Which Is Subjected to Alternative Splicing}

To elucidate the location of the neuronal insert of c-src at the genomic DNA level we designed a pair of oligonucleotide primers flanking the intron between exons 3 and 4 . Genomic DNA either from pooled fish organs (testis, liver, brain) or from fish total brain was used and the resulting PCR product was in every case a single band of $1.6 \mathrm{~kb}$ (Fig. 4, lanes 2-4). This band was subjected to an analytical Pst I restriction enzyme digestion which revealed three bands of $0.95 \mathrm{~kb}, 0.4 \mathrm{~kb}$, and $0.25 \mathrm{~kb}$ (Fig. 4, lane 5). Due to the second Pst I site in the 


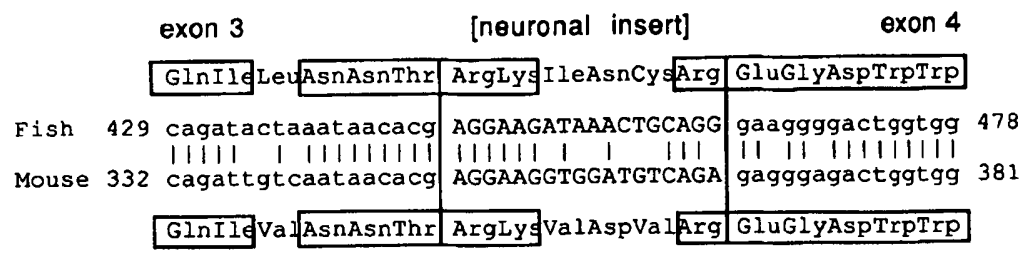

Fig. 3. Sequence comparison between fish and mouse c-src neuronal insert and flanking regions of exons 3 and 4 . Identical amino acids are boxed. Mouse c-src sequence was taken from Martinez et al. (1987). The amino acid sequence of the chicken neuronal insert (Levy et al., 1987) is identical to that of mouse.

region between exons 3 and 4 an exact location of the neuronal insert was not possible. Therefore an oligonucleotide primer of the neuronal insert sequence (\#SNR) was designed. A PCR with genomic DNA from $X$. helleri and primers \#S372 and \#SNR yielded a fragment of about $1.2 \mathrm{~kb}$ (Fig. 4, lane 8 ). The generation of only one PCR product confirmed the presence of the insert between exons 3 and 4 in the genomic c-src locus. The size of this PCR product localized the neuronal insert about $1.13 \mathrm{~kb}$ downstream from the end of exon 3 and about $0.33 \mathrm{~kb}$ upstream from the beginning of exon 4 (after accounting for the exon 3 and exon 4 sequences present in the PCR product).

\section{Neuronal and Non-Neuronal Forms Are Characteristic for c-src But Are Not Found for c-yes}

To answer the question of whether c-yes exhibits the same polymorphism of a neuronal and nonneuronal form, we used a similar approach to that for c-src. From a cloned cDNA of $X$. helleri c-yes (Hannig, Ottilie, and Schartl, submitted) we designed a pair of oligonucleotide primers for PCR, encompassing $412 \mathrm{bp}$ around the border of exons 3 and 4 where an c-src homologous neuronal insert would be expected. RT-PCR of $X$. helleri brain and liver RNA preparations revealed only one band with the expected fragment length (Fig. 2, lanes 8 and 9), but no additional amplification product of larger size, which would be indicative of a neuronal form of c-yes.

\section{Hydra c-src Does Not Encode an Analogous Neuronal Form}

Based upon the cDNA sequence of the $H$. attenuata $s r c$-related tyrosine-kinase gene $s t k$ (Bosch, T.C.G., unpublished), a pair of 22 mer oligonucleotides was prepared which span $113 \mathrm{bp}$ of the region analogous to the exon $3 / 4$ boundary of the vertebrate c-src gene. PCR amplification was performed with these two oligonucleotides by using either Hydra genomic DNA or stk cDNA as templates. In both cases an amplification product of $157 \mathrm{bp}$ was observed (data not shown), demonstrating that no analogous intron exists in the Hydra genomic locus.

\section{DISCUSSION}

The experiments reported here show that a lower vertebrate (the teleost fish Xiphophorus) possesses a neural form of c-src mRNA. Analogous to the situation in chicken (Levy et al., 1987) and in mouse (Martinez et al, 1987), this form arises due to the presence of an additional 18 basepair insertion between exons 3 and 4. Differential splicing of this mini-exon specifically within certain cells of neural origin gives rise to this alternative transcript form. Our data represent the first direct demonstration that this mini-exon does indeed reside within the intron separating exons 3 and 4 . Our results are inconsistent with a rearrangement of the genomic c-src locus specifically within neural tissue, which had remained a theoretical possibility. The fish c-yes gene does not give rise to two forms of mRNA in brain. This is interesting because the c-yes gene is the member of the $s r c$ gene family of tyrosine kinases most closely related to c-src and has also been shown to be expressed in neural tissue (Sudol et al., 1988). The question arises as to whether a neuronal c-yes transcript form could be present, but in such a small relative amount so as to be 

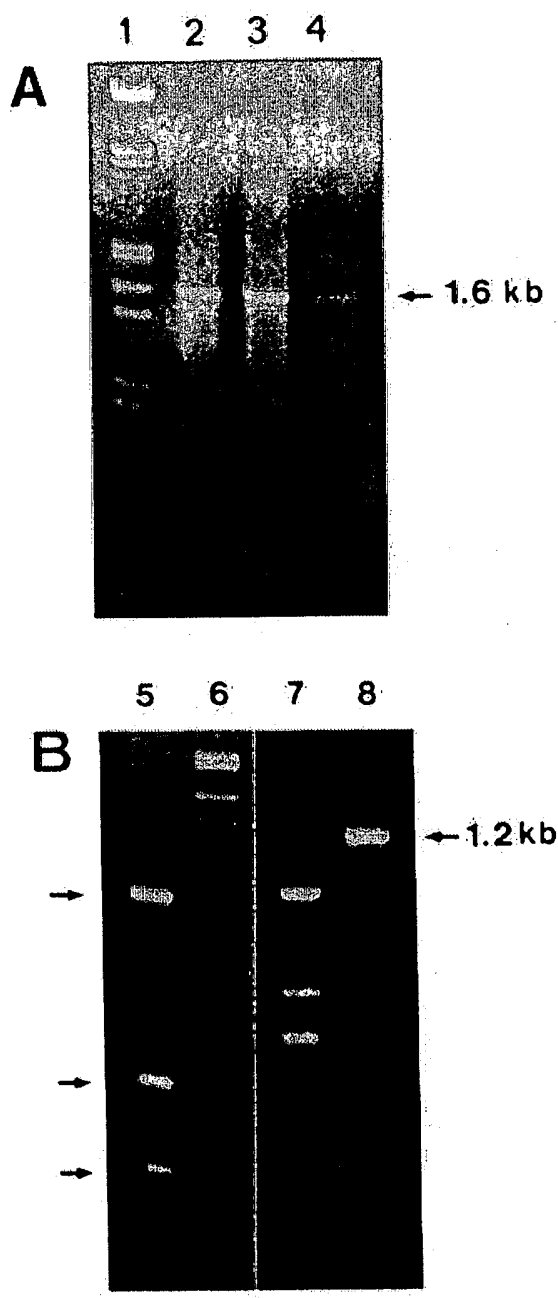

Fig. 4. PCR of genomic DNA from Xiphophorus. A: $1 \%$ agarose gel with PCR products of reactions performed with src primers \#S372 and \#S515R. (2) $X$. helleri DNA from pooled organs, (3) X.maculatus DNA from pooled organs, (4) $X$. helleri $^{T_{u}-S d}$ DNA from brain (approx. one-fifth the template amount as in lanes 2 and 3). (1) Molecular weight marker $\lambda /$ EcoR I + Hind III. B: $1.5 \%$ agarose gel. (5) PCR product as in A lane 2 after digestion with Pst I. (6) molecular weight marker $\lambda / E c o R ~ I+$ Hind III. (7) Molecular weight marker pBR322/EcoR I + Hinf I. (8) PCR product of $X$. helleri DNA (pooled organs) and src primers \#S372 and \#SNR.

undetectable via this sort of RT-PCR analysis; $4 \mu \mathrm{g}$ brain total RNA was used for the RT-PCR amplification, which represents approximately $0.03 \mathrm{fmol}$ or $10^{7}$ copies of the c-yes transcript (F. Raulf, unpublished). Control experiments of ours under very similar conditions to those employed here (S. Robertson and J. Wittbrodt, unpublished) have shown successful PCR amplification from as few as $10^{4}$ target sequences. Therefore, if a neuronal form was present at a relative level as low as $0.1 \%$ of the non-neuronal form, a visible band would have been expected.

The sequence of the fish neuronal insert, when compared to that of the mouse (Martinez et al., 1987) and chicken (Levy et al., 1987), has several interesting features. First, the percentage identity at both the nucleic acid and amino acid level would appear to be lower than in the immediately adjacent regions of exons 3 and 4 (Fig. 3). Of the six amino acid residues, three are identical and two are conservative changes (lle $\rightarrow$ Val;Asn $\rightarrow$ Asp), with the three changes occurring in the middle of the neuronal insert. Second, a preponderance of polar sidegroups in the mouse, chicken, and fish neuronal inserts leads to a hydrophilic stretch of amino acid residues with a significant probability for exposure at the surface of the protein. This conservation of the hydrophilic nature of the neuronal insert suggests that this feature may play an important role in the tissue-specific function of pp60 $60^{\mathrm{c}-s \mathrm{rc}+}$.

We have shown that the fish c-src gene encodes, by way of alternative splicing of a mini-exon located between exons 3 and 4 , a neuronal-specific mRNA form whereas the fish c-yes gene apparently does not. This would suggest that the neuron-specific sequence was not present prior to the src/yes gene duplication event, calculated to have occurred approximately 550 million years (Myr) ago (Robertson et al., submitted). This raises two possibilities pertaining to the evolutionary origin of this particular sequence; one, that a sequence containing the $18 \mathrm{bp}$ mini-exon inserted into the c-src intron separating exons 3 and 4 sometime between the emergence of the protochordates (i.e., approximately $550 \mathrm{Myr}$ ago) and the divergence of the teleost fish lineage approximately $400 \mathrm{Myr}$ ago; or two, that this miniexon evolved specifically within the c-src gene lineage from a pre-existing sequence within this intron found in the common progenitor of the c-src and c-yes genes. Direct sequence analysis of the respective c-src and c-yes introns may help to distinguish between these two possibilities.

If the proposed timing for the appearance of this neuronal mini-exon is correct, then no neuronal insertion should be detected in c-src sequences from evolutionarily more primitive organisms. In Drosophila, several $s r c$-related sequences have been characterized, none of which have introns between their exon 3 and 4 analogous sequences (Hoffmann et al., 1983; Gregory et al., 1987). Therefore, a corresponding mini-exon in the analogous position is not found for the Drosophila src-related loci. In Hydra, we report here that no analogous intron exists between the sequences of the src-related locus corresponding to the vertebrate c-src exons 3 and 4 . This again discounts the possibility of an alternative splicing 
mechanism in Hydra analogous to that seen in vertebrates.

The presence of the neuronal mini-exon only in the vertebrate c-src gene must be reconciled with two sets of observations: first, neuronal-specific expression of the c-src gene has been observed well prior to the emergence of the protochordates, e.g., Drosophila (Simon et al., 1985), and Hydra (Schartl et al., 1989b); and second, the c-yes gene, a very closely related member of the src family of tyrosine kinases which, however, lacks a neuronal mini-exon, is also expressed in neural tissue (Sudol et al., 1988). Therefore the neuronal mini-exon is not the basis for this tissue specificity of expression, suggesting that it is possibly involved in a vertebrate-specific neuronal function of the c-src gene.

\section{ACKNOWLEDGMENTS}

We thank J. Wittbrodt for many valuable suggestions concerning PCR. We are grateful to T.C.G. Bosch for sharing his unpublished sequence data of the Hydra $s r c$-related gene stk and to G. Hanning and S. Ottilie for sharing their unpublished sequence data of fish c-yes. We thank R. Mertz (Genzentrum Martinsried) for the synthesis of oligonucleotides. This work was supported by the Bundesministerium für Forschung und Technologie (Schwerpunkt: Gentechnologie), the Stiftung Volkswagenwerk, and the Max-Planck-Gesellschaft. The work contains part of the Ph.D. thesis of F.R.

\section{REFERENCES}

Anderson SK, Gibbs CP, Tanaka A, Kung HJ, Fujita DJ (1985): Human cellular src gene: Nucleotide sequence and derived amino acid sequence of the region coding for the carboxylterminal two-thirds of pp60-src. Mol Cell Biol 5:1122-1129.

Barnekow A, Schartl M (1984): Cellular src gene product detected in the freshwater sponge Spongilla lacustris. Mol Cell Biol 4: 1179-1181.

Barnekow A, Gessler M (1986): Activation of the pp60i-src kinase during differentiation of monomyelocytic cells in vitro. EMBO J 5:701-705.

Barnekow A, Schartl M (1987): Comparative studies on the src protooncogene and its gene product pp60 $60^{c-s r c}$ in normal and neoplastic tissues of lower vertebrates. Comp Biochem Physiol 87B: 663-670.

Blin N, Stafford W (1976): A general method for isolation of high molecular weight DNA from eukaryotes. Nucleic Acids Res 3:2303-2308

Brugge JS, Cotton PC, Queral AE, Barrett JN, Nonner D, Keane RW (1985): Neurones express high levels of a structurally modified, activated form of pp60-src . Nature 316:554-557.

Brugge J, Cotton P, Lustig A, Yonemoto W, Lipsich L, Coussens P, Barrett JN, Nonner D, Keane RW (1987) Characterization of the altered form of the c-src gene product in neuronal cells. Genes Dev 1:287-296.

Chirgwin JM, Przybyla AE, MacDonald RJ, Rutter WJ (1979): Iso- lation of biologically active ribonucleic acid from sources enriched in ribonuclease. Biochemistry 18:5294-5299.

Cotton PC, Brugge JS (1983): Neural tissues express high levels of the cellular src gene product pp606-src. Mol Cell Biol 3:1157-1 162.

Devereux J, Haeberli P. Smithies O (1984): A comprehensive set of sequence analysis programs for the VAX. Nucleic Acids Res 12:387-395

Fults DW, Towle AC, Lauder JM, Maness PF (1985): pp60'ssrc in the developing cerebellum. Mol Cell Biol 5:27-32.

Gee CE, Griffin J, Sastre L, Miller LJ, Springer TA, Piwnica-Worms H, Roberts TM (1986): Differentiation of myeloid cells is ac-

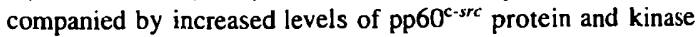
activity. Proc Natl Acad Sci USA 83:5131-5135.

Gessler M, Barnekow A (1984): Differential expression of the cellular oncogenes c-src and c-yes in embryonal and adult chicken tissues. Biosci Rep 4:757-770.

Golden A, Nemeth SP, Brugge JS (1986): Blood platelets express high levels of he pp60 6 -src specific tyrosine kinase activity. Proc Natl Acad Sci USA 83:852-856.

Gregory RJ, Kammermeyer KL, Vincent WS III, Wadsworth SG (1987): Primary sequence and developmental expression of a novel Drosophila melanogaster src gene. Mol Cell Biol 7: 2119-2127.

Hoffmann FM, Fresco LD, Hoffmann-Falk H, Shilo BZ (1983): Nucleotide sequences of the Drosophila src and $a b l$ homologs: Conservation and variability in the src family oncogenes. Cel 35:393-401.

Hunter T, Cooper JA (1985): Protein-tyrosine kinases. Annu Rev Biochem 54:897-930.

Kallman KD (1975): The platyfish, Xiphophorus maculatus. In King RC (ed): "Vertebrates of Genetic Interest." New York: Plenum Press, pp 81-132.

Kuhn C, Vielkind U, Anders F (1979): Cell cultures derived from embryos and melanoma of poeciliid fish. In Vitro 15:537-544.

Le Beau JM, Wiestler OD, Walter G (1987): An altered form of pp60 $0^{c-s r c}$ is expressed primarily in the central nervous system. Mol Cell Biol 7:4115-4117.

Levy BT, Sorge LK, Meymandi A, Maness PF (1984): pp60 c-src kinase is in chick and human embryonic tissues. Dev Biol 104: 9-17.

Levy JB, Dorai T, Wang LH, Brugge JS (1987): The structurally distinct form of pp60 $60^{c-s i c}$ detected in neuronal cells is encoded by a unique c-src mRNA. Mol Cell Biol 7:4142-4145.

Lynch SA, Brugge JS, Levine JM (1986): Induction of altered c-src product during neural differentiation of embryonal carcinoma cells. Science 234:873-876.

Maness PF (1986): pp60'-src encoded by the proto-oncogene c-src is a product of sensory neurons. J Neurosci Res 16:127-139.

Maness PF, Aubry M, Shores CG, Frame L, Pfenninger KH (1988) c-src gene product in developing rat brain is enriched in nerve growth cone membranes. Proc Natl Acad Sci USA 85:50015005 .

Maniatis T (1982): “Molecular Cloning.” Cold Spring Harbor: Cold Spring Harbor Laboratory.

Martinez R, Mathey-Prevot B, Bernards A, Baltimore D (1987): Neuronal pp $60^{\text {c-src }}$ contains a six-amino acid insertion relative to its non-neuronal counterpart. Science 237:411-415.

Mäueler W, Raulf F, Schartl M (1988a): Expression of proto-oncogenes in embryonic, adult, and transformed tissue of Xiphophorus (Teleostei: Poeciliidae). Oncogene 2:421-430.

Mäueler W, Barnekow A, Eigenbrodt E, Raulf F, Falk HF, Telling A, Schartl M (1988b): Different regulation of oncogene expression in tumor and embryonal cells of Xiphophorus. Oncogene 3 : $113-122$. 
Öfverstedt LG, Hammarström K, Balgobin N, Hjerten S, Pettersson U, Chattopadhyaya J (1984): Rapid and quantitative recovery of DNA fragments from gels by displacement electrophoresis (Isotachophoresis). Biochem Biophys Acta 782:120-126.

Raulf F, Mäueler W, Robertson SM, Schartl M (1989): Localization of cellular src mRNA during development and in the differentiated bipolar neurons of the adult neural retina in Xiphophorus. Oncogene Res (in press).

Saiki RK, Gelfand DH, Stoffel S, Scharf SJ, Higuchi R, Horn GT, Mullis KB, Erlich HA (1988): Primer-directed enzymatic amplification of DNA with a thermostable DNA polymerase. Science 239:487-491.

Schartl M, Barnekow A (1982): The expression in eukaryotes of a tyrosine kinase which is reactive with $\mathrm{pp} 60^{\mathrm{v}-\mathrm{src}}$ antibodies. Differentiation 23:109-114.

Schart M, Barnekow A (1984): Differential expression of the cellular src gene during vertebrate development. Dev Biol 105:415422.

Schartl M, Wittbrodt J, Mäueler W, Raulf F, Adam D, Hannig G, Telling A, Storch F, Andexinger S, Robertson SM (1989a): Oncogenes and melanoma formation in Xiphophorus (Teleostei: Poeciliidae). In Schröder JH, Schartl M (eds): "New Trends in Ichthyology." Hamburg: P. Parey, in press.

Schartl M, Holstein T, Robertson SM, Barnekow A (1989b): Prefer-

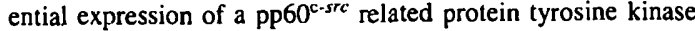
activity in nerve cells of the early metazoan Hydra (Coelenterates). Oncogene (in press).

Simon MA, Drees B, Kornberg T, Bishop JM (1985): The nucleotide sequence and the tissue-specific expression of Drosophila c-src. Cell 42:831-840.

Sorge LK, Levy B, Maness PF (1984): pp60 $0^{\text {c-src }}$ is developmentally regulated in the neural retina. Cell 36:249-257.

Stehelin D, Varmus HE, Bishop JM, Vogt PK (1976): DNA related to the transforming gene(s) of avian sarcoma viruses is present in normal avian DNA. Nature 260:170-173.

Sudol M, Alvarezbuylla A, Hanafusa H (1988) Differential developmental expression of cellular yes and cellular src proteins in cerebellum. Oncogene Res 2:345-355.

Takeya T, Hanafusa $H$ (1983): Structure and sequence of the cellular gene homologous to the RSV src gene and the mechanism for generating the transforming virus. Cell 32:881-890.

Vardimon L, Fox LE, Moscona AA (1986): Accumulation of c-src mRNA is developmentally regulated in embryonic neural retina. Mol Cell Biol 6:4109-4111.

Wakamatsu Y, Oikawa A, Obika M, Hirobe T, Ozato K (1984): Fish hereditary melanoma cell lines of different degrees of cell differentiation. Dev Growth Differ 26:503-513.

Walaas SI, Lustig A, Greengard P, Brugge JS (1988): Widespread distribution of the c-src gene product in nerve cells and axon terminals in the adult rat brain. Mol Brain Res 3:215-222.

Wittbrodt J, Erhardt W (1989): An inexpensive and versatile computor-controlled PCR machine using a Peltier element as a thermoelectric heat pump. TIG 5:202-203. 